\title{
Microfinance and the Decision to Invest in Children's Education ${ }^{+}$
}

\author{
PV Viswanath ${ }^{(1)}$ \\ Lubin School of Business, Pace University, 1 Pace Plaza, New York, NY 10038, USA; pviswanath@pace.edu; \\ Tel.: +1-(212)-618-6518 \\ † The work in this paper was done with the assistance of students in my India Field Study course, which I \\ taught in Fall 2015 with a visit to India in January 2016. The names of the students, who participated in the \\ course are: Caroline A Alcindor, Ryan E Barone, Ornella S Beresi-Greif, Sergio F Borjas, Frantzceska Cheron, \\ Andrew P Crocitto, Ronit R Desai, Gabriella D Ferrara, Ashley A Heller, Genesis Y Jaya Ron, Jozef M Lampa, \\ Zhi Hong Mao, Tiffany N Quinto, Morgan Steadwell, Hantze M Toureau and Anastasia Vasilakos.
}

Received: 5 January 2018; Accepted: 26 January 2018; Published: 1 February 2018

\begin{abstract}
Although one of the primary objectives of microfinance has been the reduction of poverty through the provision of credit for income-generating purposes, evidence of its impact on poverty has been mixed. Even if there is no direct impact of microfinance, there may be an indirect positive impact through the effect of microcredit availability on families' decisions to invest in their children's education. In this paper, I describe a study undertaken to gauge the impact of microcredit availability on education expenditures for children of clients of a South Indian microfinance institution. I first look at some determinants of the demand for education and then go on to consider what we know about how microcredit affects this demand. I find that microcredit has an impact on the demand for education as mediated by wealth effects and status effects, i.e., microloans increase spending on education the greater the wealth and the greater the social status of the family. Focus group interviews suggest that the impact of microcredit on the demand for education comes mainly from the greater access to financial resources and, to a lesser degree, from an accompanying appreciation of the value of education.
\end{abstract}

Keywords: microfinance; education; human capital; social status; India

JEL Classification: O16; D14; G21; L31; I22; I25

\section{Introduction}

Although one of the primary objectives of microfinance has been the reduction of poverty through the provision of credit for income-generating purposes, evidence of its direct impact on poverty has been mixed. ${ }^{1}$ However, given that money is fungible, it is possible that microcredit is used for expenditures other than the business purpose for which the microloan was designated. High return capital expenditures, in particular, have the potential to substantially increase borrower wealth and future consumption; this is, arguably, even more so if these expenditures are on human capital—for example, on education. For example, Mobolaji (2010) finds a strong complementarity between education and physical capital on economic growth in sub-Saharan Africa, while Lee and Kim (2009), in a cross-country study, find that secondary education is important in engendering long-run economic growth in developing countries. More directly, Yang (2004), working with Chinese panel data, suggests that education might be able to improve allocative efficiency. Hulme and Shepherd (2003) note that, in addition

1 See, e.g., Cull et al. (2009), as well as the discussion in Viswanath (2018). 
to income deprivation, poverty is also characterized by deprivation of income. Elsewhere (Hulme 2007), borrowing a classification scheme used by the World Bank, Hulme discusses the importance of three things in battling chronic poverty: opportunity (economic growth and employment), empowerment and security; education is certainly part of the opportunity leg of this three-cornered stool. Barrientos and Hulme (2008) note that particularly in developing countries, social protection relies on "productive employment and asset building;" education is increasingly important in ensuring employment and asset accumulation. Thus, if microfinance results in increased expenditure on education, it may well have a positive and long-term impact on the lives of borrowers even if the direct impact of microcredit on borrower welfare is difficult to demonstrate. Others have suggested that poverty, itself, should be redefined to include multi-dimensional aspects, including education and health (Alkire and Sumner 2013; Grosse et al. 2008).

With this in mind, I describe, in this paper, a study undertaken to gauge the impact of microfinance availability on education expenditures for borrowers' children. My paper is one of the few that examines this issue. Maldonado and Gonzalez-Vega (2008), using data from household surveys in Bolivia, look at the impact of microfinance on the demand for education. Tarozzi et al. (2015) study the relationship between micro-credit and primary school attendance in Ethiopia; Augsburg et al. (2015) perform a similar study in Bosnia and Herzegovina. Wydick (1999) examines the effect of access to credit on schooling investment in children in rural Guatemala. Khandker (1998) also considered education in his study of the impact of microfinance in Bangladesh. Adjei et al. (2009) consider the role of education in the effectiveness of microfinance in Ghana, but they do not look at the education decision, per se. My paper adds to this meager research in that it is the first to examine this subject in the context of India. Furthermore, in contrast to previous research which looked at very underdeveloped regions with low human capital indices, we look at the state of Kerala in South India, which has a high life expectancy and literacy rate. We also look at parents' time-investment in their children's education, as well as their financial investment. Finally, our paper is the first to look at the role of social class in how microfinance impacts the demand for investment. In contrast to most previous studies, I find that microfinance has a significant impact on the demand for education as mediated by wealth effects and status effects, i.e., microloans increase spending on education, the greater the wealth and the greater the social status of the family. Focus group interviews suggest that the impact of microcredit on the demand for education comes mainly from the greater access to financial resources and, to a lesser degree, from an accompanying appreciation of the value of education.

I first look at some determinants of the demand for education that are relevant to our purpose and then go on to consider what we know about how microfinance affects this demand.

\subsection{The Demand for Education}

I review here existing studies on some determinants of the demand for children's education and the extent to which microfinance could affect demand; in particular, I look at family income, risk attitudes, social class and health. Jacoby and Skoufias (1997) present evidence that consumption and schooling investment decisions are not separable if financial markets are incomplete. For example, they find that seasonal variations in school attendance (replaced by child labor) are a form of self-insurance that significantly reduces the schooling of children in households that are vulnerable to risk and these variations are a costly form of insurance, particularly for poorer households. Behrman and Skoufias (2010) note that the impact of imperfections in capital markets on the poor may be compounded since they tend to have relatively high discount rates. The very poor live close to subsistence and so a small negative shock could lead to malnourishment or starvation; since they are not able to avert this risk by borrowing in capital markets or insuring in risk markets, they tend to have high discount rates. Higher income is likely to lead to lower risk aversion and less of a need to substitute children's labor for time spent on education. Lower risk aversion and lower discount rates lead to a greater willingness to invest in increased capital investment, including human capital. Access to financial services such as credit and insurance are likely to strengthen this effect. In support 
of this, Behrman and Knowles (1999) show that there is an empirical association between parental long-run income measures and child schooling in Vietnam.

The caretaker's gender is also likely to play a role in the decision to educate children. Esther Duflo (2012) documents that women have different preferences regarding how to use resources in the family compared to men; for example, she notes that women spend more on children's food than men do. However she cites an interesting study by Edmonds (2006) who uses a reform of the pension system in South Africa to study the impact of the pension program on education. Edmonds compares school enrollment of adolescents in families where there is an elderly member who is eligible for the pension and in families where there is an ineligible elderly member. He finds that, compared to those in families with ineligible elders, children are more likely to be in school when they live with an eligible man than with an eligible woman! So women might care more about food, but men might care more about education. On the other hand, Behrman and Rosenzweig (2002) find the opposite effect-that women show a stronger preference for educating their children. And what about the gender of the child? Microfinance has long been touted as empowering women. While there is no direct channel relating microfinance to education for female versus male children, there may be an implicit bias in the decision to grant microcredit if there are women children in the family; also, if availability of credit is greater for women rather than men and if education improves the ability to obtain and use microcredit, it would make sense for families to invest more in girls' education rather than in boys' education. If so, the availability of microfinance might be more positive for girl children's education than for boy children.

Another factor that affects the decision to educate children is the family's class status. Breen and Goldthorpe(1997) propose a framework to explain class differences in educational choices and educational outcomes involving three components: (a) the subjective probability that different educational careers can successfully be completed; (b) the expected costs when doing so, and, in particular; (c) the returns from educational credentials being likely to maintain the families' class position. According to Breen and Goldthorpe (1997), lower class families are less likely to choose higher education for their children, since the costs are more burdensome. Furthermore, assuming a positive correlation between class status and learning capabilities, likelihood of successful completion is also lower for lower class students, particularly in more demanding higher education courses. Stocké (2007) tests this model on a sample of German families and finds that the social class of origin exerts a strong effect on children's educational attainment, with lower class families choosing educational paths that were likely to keep their children in their existing social class. In terms of implications for microfinance, the Breen-Goldthorpe theory suggests that the impact of microfinance on the demand for education is likely to be stronger for families from higher classes, since the returns from educational credentials is likely to be higher to the extent that microcredit increases the likelihood of business success.

Schneider et al. (2007) use data from the German Socio-Economic Panel (SOEP), a representative longitudinal study of private households in Germany to study the effect of health on education. Overall, they find a dominant substitution effect of health on education: good health implies higher learning efficiency so that the same income can be achieved with lower investment in advanced training. However, they also find an investment effect: among individuals with higher education, better health leads individuals to invest more in additional training. If these results can be extrapolated to other environments and if the substitution effect is greater, access to microfinance could lead to a lower investment in education. On the other hand, their investment effect could imply that with microcredit providing better nutrition, investment in education would increase.

\subsection{Evidence of the Impact of Microfinance on the Demand for Education}

There is some evidence to suggest that microfinance can have an impact on the demand for education. Maldonado and Gonzalez-Vega (2008) develop a theoretical model, which they test using survey data from Bolivia. They find conflicting implications from their empirical model; on the one hand, microfinance may increase the demand for education as a result of income, risk-management, 
gender, and information effects; on the other hand, credit-constrained households that cultivate land may discover new demands for child labor for farming (or perhaps taking care of siblings while the mothers operate a new or expanded business). Wydick (1999) also found that microcredit could increase "the return to child labor and thus the opportunity cost of schooling." Augsburg et al. (2015) come to a similar conclusion; they find a lower level of schooling among teenagers in poorer families obtaining microfinance. Tarozzi et al. (2015) use data from a randomized control trial in rural Ethiopia to study the impact of microfinance on a number of socioeconomic outcomes, one of them being schooling; they find no impact on schooling. In contrast to the above studies, Khandker (1998), did find a positive impact of microfinance on parents' investment in children's education, especially for boys. Adjei et al. (2009) study cross-sectional data from clients of Sinapi Aba Trust, a microfinance NGO in Ghana. They find that participation in the program enabled established clients to own savings deposits and subscribe to a client welfare scheme which served as insurance to pay off debts in times of illness or death. Established clients were also found to be in a better position to contribute towards the education of their children and payment of healthcare for members of their households as well as contribution towards the purchase of household durables.

The conclusion that we can draw from the studies on educational investment is that improved financial circumstances are likely to increase investment in education, particularly if families are from higher socio-economic classes and are in good health or where the parents themselves are already educated. The existing microfinance studies, by and large, do not confirm the expected positive relation between microfinance and education; in fact, Wydick (1999), Maldonado and Gonzalez-Vega (2008) and Augsburg et al. (2015), all found that the opposite is the case. None of the studies discussed here looked at the effect of family status or class, while only Maldonado and Gonzalez-Vega (2008) and Khandker (1998) looked at the effect of the gender of the child on microfinance recipients' decisions to invest in education.

\subsection{Education in Kerala}

The situation in Kerala is somewhat different from that in most parts of Africa or rural South America in that income levels are generally higher, so it is not easy to extrapolate from the above studies. On the other hand, education is still costly. Even though there are no fees for primary education, the students still have to incur special fees, examination fees, the cost of reading and writing materials, clothing, travelling, study tours, donation to PTAs (parent-teacher associations) and, increasingly, private tuition outside of school. Costs for college students are even higher, particularly for those not living at home. One study found that the private expenses of engineering students in the government college who were staying away from their homes for studies was more than half of the average household income of Kerala (Kumar and George 2009). More recently, there has been less government aid for education. For example, a major trend in the nineties was the proliferation of unaided schools and the growth of self-financing courses and institutions in the higher education and technical education sectors that are not aided by private organizations or by the government. They try to recover the entire cost from the students. Furthermore, $26 \%$ of the schools up to Standard Ten were unaided private schools in 2006-2007.

In spite of the high average income levels in Kerala, access to education for BPL (below-the-poverty-line) families can still be a problem. George (2001), surveying the BPL families in one rural area and one urban periphery in the state, found that the enrolment ratio of the poor was very low in the higher classes. The ratio was 100 percent at the primary level (age 6 to 11) and $66.7 \%$ at the middle school level (age 11 to 14). However at the secondary level (age 14 to 18), the ratio fell drastically to $25 \%$. The enrolment ratio among the poor at the higher education level (age 18 and above), furthermore, was even worse at 1.9. The Human Development Report for Kerala (United Nations Development Programme UNDP) came to the conclusion that the deprived groups 
(SC/ST and OBC groups) lag behind the others in the achievement of this basic functioning. ${ }^{2}$ Viswanath (2015) discusses education in Kerala and demonstrates its importance to the Kerala economy.

\subsection{Our Study}

Following the tentative results of the microfinance studies described above, there is certainly need for a further look at the effect of access to microfinance on investment in education. While substitution effects seemed to be prevalent in Bolivia and Guatemala, this may not be the case in an environment like Kerala with a better developmental record. We have, then, two competing hypotheses: one, access to microfinance increases investment in education, and two, access to microfinance may decrease investment in education because children's labor is needed for expanding businesses. I also study the effect of respondents' social status on the education investment decision. Finally, following the well-known preference for male children in India, I examine the role of gender. My study has two methodological innovations compared to previous work. One, I look at investment in children's education not only in terms of monetary investment, but also in terms of time investment; and two, I look at class effects, using a variety of measures for class. Table 1 lays out the key categories of independent variables that we look at and the predicted relationships with educational investment.

Table 1. Description of key variables and their expected effects on children's education.

\begin{tabular}{cccc}
\hline Variable & $\begin{array}{c}\text { Expected } \\
\text { Sign }\end{array}$ & $\begin{array}{c}\text { Sign of Interaction } \\
\text { with Microcredit }\end{array}$ & Theoretical Basis \\
\hline Microcredit & $\begin{array}{c}\text {-ve } \\
+\mathrm{ve}\end{array}$ & $+\mathrm{ve}$ & $\begin{array}{c}\text { Substitution Effects } \\
\text { Reduced Risk Aversion }\end{array}$ \\
\hline Class & $+\mathrm{ve}$ & Breen-Goldthorpe \\
\hline Wealth & $+\mathrm{ve}$ & $+\mathrm{ve}$ & $\begin{array}{c}\text { High returns to education for members of } \\
\text { families involved in business }\end{array}$ \\
\hline Gender of child (Male $=1)$ & $+\mathrm{ve}$ & $-\mathrm{ve}$ & $\begin{array}{c}\text { Reduced risk aversion } \\
\text { Microfinance directed towards women }\end{array}$ \\
\hline Number of children & $-\mathrm{ve}$ & $-\mathrm{ve}$ & $\begin{array}{c}\text { Decreasing returns from educated children } \\
\text { Decreasing Wealth Effects }\end{array}$ \\
\hline
\end{tabular}

Possible channels of the effect of microfinance on education expenditures are: (a) through higher wealth flowing from microcredit which would lead to more expenditure on education, assuming that education is a normal good; and (b) social awareness that may accompany access to microcredit leading to a better understanding of the economic value of education. We will consider this question in our analysis below. More information on this issue was also obtained during the focus-group interviews, which will be discussed in Section 4 .

\section{Data}

The information for this study comes from two sources. The first source is a survey administered to 38 borrowers on 3 and 4 November 2015 at two of the Kollengode centers of a Kerala MFI (microfinance institution) called SRI (Society for Rural Improvement) - 20 in Kallatukulambu village and 18 in Thoompana village. ${ }^{3}$ The survey covered all the borrowers at these two centers, which were chosen from the point of view of convenience with respect to the follow-up student visit to SRI, which took place in January 2016, a factor which should not be related to the questions studied. As such,

2 The information about George (2001) findings is taken from Kumar and George (2009).

3 Questionnaire used for survey available in Appendix A. 
there should not be any selection bias issues. SRI is a microfinance institution founded by Dr. Prabhakar in February 1996 on the Grameen Bank model, in Kollengode district in the state of Kerala in South India. SRI makes loans to individual women; however, each borrower is required to be in a group of five women for the purpose of training, loan disbursement and collection. Some of the business purposes for which SRI loans are provided are purchase of a dairy cow, canteens, grocery stores, small-scale garment manufacturing, areca nut processing, tailoring, manufacture of food products such as Indian pickles, brass utensil making, and poultry farming. ${ }^{4}$ The survey instrument was constructed by the author, but was administered by SRI employees during 3 and 4 November 2015. The second source is a focus group process that is further discussed in Section 4 below.

The dependent variable, investment in children's education, is measured using the data available from the survey, in two different ways: one, the rupee expenditure on the children's education per child (ExpPerChild); and two, the time invested in the children's education by the parents per child (TimePerChild). ${ }^{5}$ While the monetary expenditure is a natural measure to consider, the inclusion of the second measure is an innovation of this study. As far as measuring the availability of microcredit, unfortunately information regarding the actual amount of loans from SRI was not available for reasons of confidentiality; hence it was necessary to use more indirect measures. I used four variables that seemed to measure access to microfinance-one, the number of loans from SRI (NumberLoans); two, the number of loans from other financial institutions (NumberOthLoans); three, the sum of all loans obtained from all financial institutions, including SRI (TotalLoans) and four, the number of years as an SRI client (measured as the year when client joined SRI-memyr). ${ }^{6}$

I use several variables to measure status. The obvious measure of status in India is caste; however, this information was not made available by the MFI and as a result, I had to resort to other measures. The parents' educational level is one possible measure of social class. However, this variable is likely to be highly correlated with income; as a result, it would be difficult to separate class effects from income effects, using this variable. Furthermore, this is likely to be the case for most of the other variables describing the parents, such as, for example, their occupation. Hence I use data pertaining to the grandparents. I use two different such measures-one, the education of the grandparents; and two, the nature of the grandparents' occupations. Historically, people's access to education was highly correlated with their caste/social status. Similarly, in caste-ridden India, occupations used to be closely tied to castes. I create an ordinal variable to measure grandparents' occupation (details in Appendix B). ${ }^{7}$ Another measure of status that I use is the medium of instruction for the children's education under the assumption that the choice of English-medium schools would indicate the social status of the family. ${ }^{8}$ There is no variation in the data on the medium of instruction for the grandparents' education-all of them studied in Malayalam-medium schools. ${ }^{9}$

4 Information obtained from communications and other material provided by SRI.

5 We also considered total expenditure (for both time and monetary outlays), rather than expenditure per child; the results were much stronger in terms of expenditure per child and only these results are reported here. We also looked at the time invested in the children's education by their siblings; we do not report these results because the results were not very informative.

6 We will only use TotalLoans in our analysis since $\mathrm{nl}$ and TotalLoans behaved similarly, but TotalLoans is more inclusive; NumberOthLoans and memyr were not significant in our regressions.

7 Given the small size, however, I decided to use it in the analysis as if it were an interval variable, even though it is only an ordinal variable. However, I confirmed my results by dividing occupations into two groups-high status and low status. It must be noted, however, that the status variable may be measuring either social status or caste or the education level of the parents. However, as reported later, none of these measures of status were significant.

8 Of course, the choice of English schools might itself be an endogenous variable which depends on the availability of financing.

9 It would have been preferable to use the grandparents' medium of instruction as a measure of status, since it could be argued that expenditure on children's education and medium of instruction are both jointly determined. However, we cannot use the medium of instruction for the grandparents, since none of the grandparents ever studied in English. 
Finally, I gather and use information on family wealth. I assume that this variable does not affect access to microfinance loans. ${ }^{10}$ The survey instrument asked for information on ownership of various kinds of vehicles such as bicycles, cars and autorickshaws; appliances, refrigerators, televisions, computers, mobile phones and gold. For gold, the survey requested a rupee value of the family's holdings. In India, particularly in South India, gold as a form of saving is considered very important and even more so by women. If so, assets in the form of gold might be more important in the parents' decision to invest in a risky and long-term investment such as education, compared to other assets. The total asset value measure was constructed by valuing the different assets using information available on the web and adding up the imputed values of the different assets. ${ }^{11}$ Table 2 provides summary statistics on some of the important variables.

Table 2. Summary Statistics.

\begin{tabular}{|c|c|c|c|c|c|c|}
\hline Variable & Description & No. Obs. & Mean & Std. Dev & Min & Max \\
\hline GoldValue & $\begin{array}{l}\text { Monetary Value of gold holdings, in } \\
\text { Indian Rupees (INR) }\end{array}$ & 37 & $29,135.14$ & $62,573.58$ & 0 & 300,000 \\
\hline TotalValue & $\begin{array}{c}\text { Total value of assets, large appliances and } \\
\text { vehicles (in INR) }\end{array}$ & 37 & $65,655.41$ & $70,787.69$ & 0 & 362,750 \\
\hline EnglishDummy & $\begin{array}{l}\text { Avg over all children of dummy variable } \\
\text { which equals } 1 \text { if med of instr is English } \\
\text { and } 0 \text { otherwise }\end{array}$ & 36 & 0.231482 & 0.365752 & 0 & 1 \\
\hline MaleDummy & $\begin{array}{l}\text { Avg over all children of dummy variable } \\
\text { which equals } 1 \text { if child is male, } 0 \text { otherwise }\end{array}$ & 37 & 0.486487 & 0.354378 & 0 & 1 \\
\hline NumberLoans & Number of loans obtained from SRI & 37 & 9.459459 & 6.035058 & 1 & 19 \\
\hline NumberOthLoans & $\begin{array}{l}\text { No. of loans obtained from other } \\
\text { fin institutions }\end{array}$ & 37 & 2.432432 & 2.723769 & 0 & 10 \\
\hline TotalLoans & Total no. of loans from all fin insts incl SRI & 37 & 11.89189 & 6.607167 & 1 & 26 \\
\hline EducInfoDummy & $\begin{array}{c}\text { Dummy variable: }=1 \text { if respondent } \\
\text { obtained information on education from } \\
\text { SRI; } 0 \text { otherwise }\end{array}$ & & 0.756757 & 0.434959 & 0 & 1 \\
\hline
\end{tabular}

\section{Results}

I now report the results of my regression analysis of the determinants of monetary (ExpPerChild) and temporal (TimePerChild) investment in children's education. I first look at each of the variables and their interaction with microcredit availability separately, viz. class status, gender of child and wealth. ${ }^{12}$ I first note that microcredit availability, by itself, has no effect on the decision to invest in

10 For-profit MFIs may, in fact, prefer to provide microloans to better-off individuals, so this assumption may not, in general, be true. However, I had several conservations with Dr. Prabhakar in which he emphasized his desire to make SRI's services available to all deserving families.

11 A television was assigned a value of Rs. 20,000 based on a new product market value of Rs. 40,000 (https:// priceraja. $\mathrm{com} /$ televisions/). A mobile phone was assigned a value of Rs. 2000, based on a new product market value of Rs. 4000 (https:/ / priceraja.com/browse/keyword-phone-with-price-list-in-india; we assumed based on casual observation that the mobile phones were not smart phone, which were valued at Rs. 40,000 at this same site). Refrigerators were valued at Rs. 8000, based on a new product value of Rs. 16,000-17,000 (http://compareindia.ibnlive.com/products/refrigerators/13). Computers were valued at Rs. 10,000, based on a new product value of Rs. 20,000 (http://compareindia.ibnlive. com/products/desktop-pcs/152). A scooty (bike) was valued at Rs. 19,750, based on a new unit value of Rs. 39,500 (http:/ / www.pricedekho.com/bikes/tvs-scooty-price-mp.html). A bicycle was valued at Rs. 5000, based on a new unit value of Rs. 10,000 (http://www.junglee.com/cycling/b/798597031). These websites were accessed in December 2015; unfortunately, most of these sites are now not active.

12 I also controlled to see if the posited relationships were affected by the average age of the grandparents on the hypothesis that the older the grandparents were, the older the parents were likely to be, and the less likely that they would be educated. Neither of these variables were significant. I also collected information on whether the children work in the parents' business; if children work in the business then, following Maldonado and Gonzalez-Vega (2008), increased availability of finances might lead to lower investment in children's education. However, most of the parents did not provide a numerical response to this question, either because children do not work in the business or because they did not want to answer the question. Thus, this variable either did not provide enough variation or did not provide information. I encountered a similar situation 
children's education (cols. 2 and 7 of Table 3). This is true for all measures of microcredit choice. However, this only measures the direct impact of microcredit on the decision to invest in children's education. I now look at the extent to which microcredit has an indirect impact on investment in education through its interaction with other more direct determinants of education investment. ${ }^{13}$

\subsection{Family Wealth}

When total wealth is measured as the sum of the estimated market values of gold and all other assets (TotalValue), it is seen to be a statistically significant determinant of educational investment, as measured in rupees (col. 5 of Table 3). Further, this effect is stronger, the greater the access to microcredit (col. 6). However, these effects are stronger when I use the value of gold (GoldValue) alone as the measure of total wealth, rather than the value of all non-gold assets plus the value of gold or the value of non-gold assets alone (cols. 3 and 4; hence, in what follows, I use the value of gold holdings as the measure of wealth.) When measuring educational investment in time, however, there is no correlation with the family's wealth (cols. 8-11 of Table 3). In short, we see that expenditure per child on education is strongly positive related to wealth. ${ }^{14}$ This is consistent with the risk aversion theory of Jacoby and Skoufias (1997), but also with the simple observation that education is a normal good. When we look at how the availability of microcredit affects this relationship, we see that the interaction term is positive. At least in the case of Kerala, the substitution scenario documented by Wydick (1999) and Maldonado and Gonzalez-Vega (2008) is rejected. Another interpretation of this hypothesis is that the marginal value of education is increased when microcredit is available due perhaps to the synergistic effects of human and financial capital. As a result, the marginal effect of wealth on investment in children's education is increasing in access to microcredit.

At the end of Section 1, I discussed the different channels by which access to microcredit might mediate the impact of wealth on the decision to invest in children's education. In order to obtain more information on this, I regress ExpPerChild (monetary investment in education) on three different variables: GoldValue (the value of gold holdings); its interaction with TotalLoans (the total number of microloans); and its joint interaction with TotalLoans and EducInfoDummy (a dummy variable which equals 1 when the family has obtained information about education from SRI and 0 otherwise). I find a strong positive effect of the joint interaction variable $(t=5.16)$ indicating that the mediation of microcredit availability on the wealth effect is stronger when the family has obtained information on education from SRI. ${ }^{15}$

with the question of whether the family reported owning a business; in any case, since all respondents were SRI clients and all SRI loans are income generating loans, all respondents would presumably own a business.

13 Microcredit availability is consistently insignificant when included in all of the regressions discussed below. Hence, we do not report regressions including microcredit availability by itself as an independent variable.

14 I also used total wealth per child as a measure of family wealth. The results were similar and are not included in the paper.

15 However, one single observation seems to be very influential in accounting for this finding. When we drop this observation (for a family with gold holdings of Rs. 300,000, which is twice as much as that for the family with the next highest holdings of gold), this effect vanishes. On the other hand, it may be argued that this observation, even if large, is still a legitimate observation; if so, then this result is not to be dismissed. In any case, even when we drop this observation and regress ExpPerChild on family wealth (GoldValue) and its interaction with access to microcredit, we can easily reject the hypothesis that both coefficients are jointly equal to zero $(\mathrm{F}(2,33)=4.29 ; p$-value $=0.022)$. Hence even though this single observation is influential in terms of the relevance of information about education, it is not influential as far as our main finding is concerned. 
Table 3. Educational Investment and Wealth.

\begin{tabular}{|c|c|c|c|c|c|c|c|c|c|c|}
\hline \multirow{2}{*}{$\begin{array}{c}\text { Variable/Specification } \\
\text { TotalLoans }\end{array}$} & \multicolumn{5}{|c|}{ ExpPerChild } & \multicolumn{5}{|c|}{ TimePerChild } \\
\hline & $\begin{array}{c}21.1759 \\
(0.34)\end{array}$ & & & & & $\begin{array}{l}-0.0147 \\
(-1.37)\end{array}$ & & & & \\
\hline TotalValue & & & & $\begin{array}{c}0.0258 \\
(6.61)\end{array}$ & $\begin{array}{c}0.0089 \\
(1.32)\end{array}$ & & & & $\begin{array}{l}0.0000 \\
(0.00)\end{array}$ & $\begin{array}{c}0.0000 \\
(1.62)\end{array}$ \\
\hline TotalValue*TotalLoans & & & & & $\begin{array}{c}0.0013 \\
(2.92)\end{array}$ & & & & & $\begin{array}{l}-0.0000 \\
(-1.64)\end{array}$ \\
\hline GoldValue & & $\begin{array}{c}0.0302 \\
(7.19)\end{array}$ & $\begin{array}{l}-0.0082 \\
(-1.20)\end{array}$ & & & & $\begin{array}{l}0.0000 \\
(0.00)\end{array}$ & $\begin{array}{l}0.0000 \\
(1.90)\end{array}$ & & \\
\hline GoldValue*TotalLoans & & & $\begin{array}{l}0.0031 \\
(6.21)\end{array}$ & & & & & $\begin{array}{l}-0.0000 \\
(-1.88)\end{array}$ & & \\
\hline constant & $\begin{array}{c}482.6368 \\
(0.57)\end{array}$ & $\begin{array}{c}-145.6018 \\
(-0.51)\end{array}$ & $\begin{array}{c}35.4954 \\
(0.18)\end{array}$ & $\begin{array}{c}-956.8801 \\
(-2.56)\end{array}$ & $\begin{array}{c}-860.3504 \\
(-2.53)\end{array}$ & $\begin{array}{l}0.6116 \\
(4.20)\end{array}$ & $\begin{array}{c}0.4220 \\
(5.33)\end{array}$ & $\begin{array}{c}0.4009 \\
(5.19)\end{array}$ & $\begin{array}{l}0.4085 \\
(0.10)\end{array}$ & $\begin{array}{c}0.3932 \\
(4.07)\end{array}$ \\
\hline R-squared & 0.0033 & 0.5961 & 0.8107 & 0.5549 & 0.6442 & 0.0507 & 0.0055 & 0.0995 & 0.0051 & 0.0781 \\
\hline No. of obs. & 37 & 37 & 37 & 37 & 37 & 37 & 37 & 37 & 37 & 37 \\
\hline
\end{tabular}

Note: ExpPerChild is the average monetary expenditure per child on education; TimePerChild is the average time per child that parents spend, per week, on helping the child study.

TotalValue is the sum of the market values of all assets and large appliances and vehicles owned by the family; GoldValue is the value of gold holdings; TotalLoans is the total number of microcredit loans, loans from SRI and loans from other financial institutions; TotalValue*TotalLoans and GoldValue*TotalLoans are the interactions of TotalValue and GoldValue with TotalLoans. $t$-stats in the second row in each cell; bolding indicates that coefficient is significant at the $5 \%$ level of significance in a two-sided $t$-test. 


\subsection{Social Status}

Table 4 shows the impact of class status on educational investment for two different measures of class status: one based on the medium of instruction of the family's children and the other based on the occupation of the grandparents. However, only the medium-of-instruction variable is correlated with investment in education (cols. 2 and 3 of Table 4). ${ }^{16}$ It might have been preferable to use the medium of instruction for the grandparents as a measure of social status, since the medium of instruction for the children's education is arguably a choice variable. Unfortunately, all grandparents who went to school were educated in the Malayalam medium; hence there is no variation across observations. Still, some support for the at-least-partially ex-ante nature of this variable is obtained by looking at a regression of EnglishDummy (measure for the children's medium of instruction) on Occupation (measure of status of grandparents' occupations, explained in Appendix B) and a measure of grandparents' level of education (number of years of schooling averaged over grandfather and grandmother). I find that the grandparents' education is strongly significant in explaining the parents' choice of medium of instruction for their children $(t$-stat $=3.43)$.

Table 4. Educational Investment and Class Status.

\begin{tabular}{|c|c|c|c|c|c|c|c|c|}
\hline \multirow{2}{*}{$\begin{array}{c}\text { Variable/Specification } \\
\text { EnglishDummy }\end{array}$} & \multicolumn{4}{|c|}{ ExpPerChild } & \multicolumn{4}{|c|}{ TimePerChild } \\
\hline & $\begin{array}{c}2707.66 \\
(2.54)\end{array}$ & $\begin{array}{c}-3246.05 \\
(-2.06)\end{array}$ & & & $\begin{array}{c}0.4763 \\
(2.58)\end{array}$ & $\begin{array}{l}0.9776 \\
(2.95)\end{array}$ & & \\
\hline EnglishDummy*TotalLoans & & $\begin{array}{l}663.18 \\
(4.49)\end{array}$ & & & & $\begin{array}{l}-0.0558 \\
(-1.80)\end{array}$ & & \\
\hline Occupation & & & $\begin{array}{l}334.57 \\
(0.69)\end{array}$ & $\begin{array}{c}107.09 \\
(0.19)\end{array}$ & & & $\begin{array}{l}0.1044 \\
(1.24)\end{array}$ & $\begin{array}{l}0.1129 \\
(1.16)\end{array}$ \\
\hline Occupation*TotalLoans & & & & $\begin{array}{l}30.54 \\
(0.85)\end{array}$ & & & & $\begin{array}{l}-0.0011 \\
(-0.18)\end{array}$ \\
\hline constant & $\begin{array}{l}128.09 \\
(0.28)\end{array}$ & $\begin{array}{l}173.77 \\
(0.48)\end{array}$ & $\begin{array}{l}205.48 \\
(0.24)\end{array}$ & $\begin{array}{l}39.36 \\
(0.04)\end{array}$ & $\begin{array}{l}0.3388 \\
(4.28)\end{array}$ & $\begin{array}{l}0.3350 \\
(4.37)\end{array}$ & $\begin{array}{c}0.2719 \\
(1.80)\end{array}$ & $\begin{array}{l}0.2781 \\
(1.78)\end{array}$ \\
\hline R-squared & 0.1595 & 0.4778 & 0.0134 & 0.0337 & 0.1636 & & 0.0420 & 0.0429 \\
\hline No. of obs. & 36 & 36 & 36 & 36 & 36 & 36 & 36 & 36 \\
\hline
\end{tabular}

Note: ExpPerChild is the average monetary expenditure per child on education; TimePerChild is the average time per child that parents spend, per week, on helping the child study. EnglishDummy is the average over all children in the family of a dummy variable which equals 1 if the child studies in English medium and 0 otherwise; Occupation is a variable that measures the family's status by means of the occupation of the grandparents (details in Appendix B); TotalLoans is the total number of microcredit loans, loans from SRI and loans from other financial institutions; EnglishDummy*TotalLoans and Occupation*TotalLoans are interactions of EnglishDummy and Occupation with TotalLoans. $t$-stats in the second row in each cell; bolding indicates that coefficient is significant at the $5 \%$ level of significance in a two-sided $t$-test.

It may be objected that this relationship between educational investment and class status is spurious in that English medium education is more expensive than Malayalam medium education. Hence even if the medium of instruction were randomly chosen, monetary expenditure on education would be positively correlated with the medium of instruction. This objection is, however, countered by the fact that we find a positive correlation also between the medium of instruction measure and the temporal investment in children's education (cols. 6 and 7 of Table 4$).{ }^{17}$

16 As described above, we constructed other measures of class status for the family, but none of them explained investment in children's education to a statistically significant extent.

17 Note that the total effect of the EnglishDummy variable is positive in the second specification in Table 4 (col. 3), even though the partial effect is negative. The total effect is computed by taking the partial direct effect of the variable and adding to it the indirect effect through the interaction variable (EnglishDummy*TotalLoans). Hence there is a positive effect of the EnglishDummy in both specifications-with and without the interaction term. This is also consistent with the positive effect of the EnglishDummy variable in the TimePerChild regressions (cols. 6, 7 in Table 4). 
We see from these results, then, that to the extent that we are able to interpret medium of instruction as a status variable, the family's social status is positively correlated with monetary investment in education, a result consistent with the Breen-Goldthorpe theory. We see that access to microcredit accentuates this relationship, as hypothesized. Interpreted in the context of the Breen-Goldthorpe theory, this suggests that families perceive microcredit as improving their odds of success in business. As far as temporal investment in children's education is concerned, the medium of instruction is positively related to it, but access to microcredit does not affect this relationship.

\subsection{Gender of Child}

From Table 5, we see that, contrary to our initial hypothesis, the gender of the child is entirely insignificant; this is similar to the finding of Maldonado and Gonzalez-Vega (2008). ${ }^{18}$ This may be because the lack of gender bias in Kerala is so strongly rooted that even better access to microcredit does not increase investment in girl children's education. For example, Dreze and Sen (1995, Table 6.1) show that the literacy rate for the segment of the population above the age of seven is $86 \%$ for females and $94 \%$ for males in Kerala, compared to $39 \%$ and $64 \%$ for all of India. Alternatively, an underlying implicit male bias may be offset by the pro-female advantages of microcredit. This is supported by more recent evidence that female employment and labor force participation has been trending downwards in Kerala since 2004 (Mathew 2015). In her study, Shalini Mathew presents evidence that what may be at play is a discouragement effect, exacerbated by widening gender pay differentials; this suggests that there may be a society wide retrogression in the area of gender equality. However, it is not only the interaction effect that is insignificant, but the direct effect as well, indicating that the gender of the children in the family is irrelevant in determining investment in children's education. This suggests that—at least for our sample—-the first interpretation may be more correct.

Table 5. Educational Investment and Gender of Children.

\begin{tabular}{ccccc}
\hline Variable/Specification & \multicolumn{2}{c}{ ExpPerChild } & \multicolumn{2}{c}{ TimePerChild } \\
\hline \multirow{2}{*}{ MaleDummy } & 56.65 & -201.95 & 0.0668 & 0.1366 \\
& $(0.05)$ & $(-0.12)$ & $(0.33)$ & $(0.48)$ \\
\hline \multirow{2}{*}{ MaleDummy*TotalLoans } & & 24.49 & & -0.0066 \\
& & $(0.23)$ & & $(-0.36)$ \\
\hline \multirow{2}{*}{ constant } & 706.90 & 692.63 & $\mathbf{0 . 4 0 4 5}$ & $\mathbf{0 . 4 0 8 3}$ \\
& $(1.01)$ & $(0.97)$ & $\mathbf{( 3 . 2 9 )}$ & $\mathbf{( 3 . 2 7 )}$ \\
\hline R-squared & 0.0001 & 0.0016 & 0.0030 & 0.0067 \\
\hline No. of obs. & 37 & 37 & 37 & 37
\end{tabular}

Note: ExpPerChild is the average monetary expenditure per child on education; TimePerChild is the average time per child that parents spend, per week, on helping the child study. MaleDummy is the average over all children in the family of a dummy variable which equals 1 if the child is male and 0 otherwise; TotalLoans is the total number of microcredit loans, loans from SRI and loans from other financial institutions; MaleDummy*TotalLoans is the interaction of MaleDummy with TotalLoans. $t$-stats in the second row in each cell; bolding indicates that coefficient is significant at the $5 \%$ level of significance in a two-sided $t$-test.

Finally, when we put all our primary variables and interaction variables together in the same regression model (Table 6), we see that access to microfinance strongly mediates the effect of the family's wealth on the decision to invest in children's education. The other variables are not significant, any longer. This may be because of the paucity of observations, but it does appear that if there is a medium of instruction effect at all, as suggested by Table 4, it seems to operate through the wealth

18 They do find gender effects, but only when the human capital (total number of years of schooling) of the entire family is included as an independent variable; however when this is broken up into the years of schooling of the father and mother separately and included separately in the regression, there is no effect. 
effect. Still, the fact that none of the variables behaves perversely even when combined in a single regression suggests that the two effects that we provided evidence for above, namely family wealth and social status, are not at odds with each other. The wealth effect, though, is clearly much stronger than the status effect.

Table 6. Educational Investment: Wealth, Gender and Social Class.

\begin{tabular}{ccc}
\hline Variable/Specification & ExpPerChild & TimePerChild \\
\hline GoldValue & -0.0126 & -0.0000 \\
& $(-1.08)$ & $(-0.12)$ \\
\hline \multirow{2}{*}{ EnglishDummy } & -22.8269 & 1.0738 \\
& $(-0.14)$ & $(1.86)$ \\
\hline \multirow{2}{*}{ MaleDummy } & 750.8096 & -0.0946 \\
& $(0.95)$ & $(-0.34)$ \\
\hline \multirow{2}{*}{ GoldValue*TotalLoans } & $\mathbf{0 . 0 0 3 4}$ & -0.0000 \\
\hline \multirow{2}{*}{ EnglishDummy*TotalLoans } & $\mathbf{( 3 . 7 1 )}$ & $(-0.31)$ \\
\hline \multirow{2}{*}{ MaleDummy*TotalLoans } & 21.5906 & -0.0414 \\
& $(0.13)$ & $(-0.73)$ \\
\hline \multirow{2}{*}{ constant } & -86.4389 & 0.0183 \\
& $(-1.60)$ & $(0.341)$ \\
\hline R-squared & 220.6766 & $\mathbf{0 . 2 6 8 5}$ \\
No. of obs. & $(0.59)$ & $\mathbf{( 2 . 0 6 )}$ \\
\hline
\end{tabular}

Note: ExpPerChild is the average monetary expenditure per child on education; TimePerChild is the average time per child that parents spend, per week, on helping the child study. TotalValue is the sum of the market values of all assets and large appliances and vehicles owned by the family; GoldValue is the value of gold holdings; TotalLoans is the total number of microcredit loans, loans from SRI and loans from other financial institutions; TotalValue*TotalLoans and GoldValue*TotalLoans are the interactions of TotalValue and GoldValue with TotalLoans; MaleDummy is the average over all children in the family of a dummy variable which equals 1 if the child is male and 0 otherwise; MaleDummy*TotalLoans is the interaction of MaleDummy with TotalLoans. EnglishDummy is the average over all children in the family of a dummy variable which equals 1 if the child studies in English medium and 0 otherwise; Occupation is a variable that measures the family's status by means of the occupation of the grandparents (details in Appendix B); EnglishDummy*TotalLoans and Occupation*TotalLoans are interactions of EnglishDummy and Occupation with TotalLoans. $t$-stats in the second row in each cell; bolding indicates that coefficient is significant at the $5 \%$ level of significance in a two-sided $t$-test.

We now discuss some focus group interviews that we administered to shed light on the role of microfinance in the family's decision to invest in their children's education.

\section{Qualitative Evidence from Focus Groups}

In January 2016, I and a group of my students visited Kollengode and talked to the women who had participated in the survey described and analyzed above. Our group was divided into four parties, with each group talking to two sets of 4 or 5 women, for a total of 37 women respondents and eight group conversations. ${ }^{19}$ During the course of the direct interviews that we conducted, we (the group of students and myself) tried to get some understanding about the factors that might have driven the results from our more systematic survey. Some of the issues that we tried to address were gender and the financing of education; education loans from other MFIs; and social status and expenditure on education. As far as the effects of microfinance on education expenditures, as mentioned above, we tried to see which of two possible channels of influence might have been more relevant-either through the higher wealth flowing from microcredit which would lead to more expenditure on

19 More information on the focus-group interviews is provided in Appendix C. 
education or through an understanding of the high returns to education for a family involved in a business enterprise.

\subsection{Financial Resources to Pay for Education}

I first discuss the possibility that access to microcredit is positively correlated with the wealth effects on education because microloans themselves increase family wealth and positively affect the family's ability to pay for education. One way that this might happen is if these microloans were available for educational purposes. Although SRI itself does not give education loans, one woman respondent did note that "I plan to utilize SRI to invest in my children's education." Information about the purpose of loans from other financial institutions was not directly collected in the survey, although information on the number of loans taken from other financial institutions was collected. On average, 9.5 loans were taken from SRI per family, whereas about 2.34 loans were taken from other financial institutions. Some of these other loans clearly were educational loans, as clarified in the face-to-face discussions that students conducted with borrowers. Other respondents indicated that they had used savings to cover tuition costs, rather than loans.

One student group reported of its respondents: "One of them is a tailor, two work at a laundry, one sells clothes and the last one works on a chicken farm. These women work very hard to get enough money to pay for their children's school expenses, which includes uniforms, books and transportation. These women are able to pay for these expenses from their income from their jobs and have not yet needed to take an education loan." In another group, only one woman, Rehmathneesa, had taken an education loan; the other women were using income-generating loans to pay school expenses for their children, including transportation costs, special exam fees, study materials, and school uniforms. In a second group, only one woman, Vijaya, out of the nine women interviewed had taken out loans solely for education; the rest either paid for tuition with their savings or with profits from their enterprises. Madura, in another group, didn't want to rely on loans to pay for tuition and instead wanted her oldest son to help pay for it with his income. In two other groups, interviewers reported that none of the parents had taken out loans for the purpose of financing an education; rather all education expenses were financed with personal savings derived from income.

From these comments, it is clear that the availability of increased resources from microfinance, either directly or indirectly (through higher income), encouraged parents and enabled them to spend on education.

\subsection{High Returns to Education as a Motivation for Educational Investment}

Here are some of the perspectives on the value of education that the interviewees shared with us. One of the women, Saji, said that she considered education to be very important because it was easier to get a job with a degree and to obtain a better financial status. One of the interviewing groups noted that, in order for microcredit to have an effect on investment in education, parents must be the ones making the decision to send their children to school. "Throughout the interview process, however, we learned that several children dropped out of school, with reasons ranging from the difficulty of school-work, to the lack of effort/desire, or simply the preference of work over learning." For example, Ambujam explained that her son "failed a subject and then was not interested in continuing school." She recognized that her son could have been more successful if he had continued education, but he had the final say, not she.

In a second group, most of the mothers being interviewed had not finished their education. Still, they too believed that their children should finish standard education in order to reap the benefit of the education that they themselves were never able to. For example, Vijaya stated: "because I only went up to 5th Standard that is why I wanted to make my children study." "Both parents and children are interested," in the children attending school, she said. For Rabaha it was quite the opposite: she explained that "she and her husband asked her children to study, but they were not interested," which is why her children did not finish their education. Rabaha recognized the importance 
of continuing education stating: "I believe that if my sons continued past 7th and 10th standard they would have made more money than they do currently." Rugmani agreed with Vijaya stating she and her husband had supported them (their children) to study.

In a third group, the interviewers found that, instead of the parents pressuring their children to continue studying, nearly all of the nine women in the group left the decision to pursue education up to their children. If their kids wanted to continue their education, then the parents would support them wholeheartedly. One exception was Madura who was insistent that her children should work as soon as they finished their education, so as to help with family income.

These comments suggest that there was a broad understanding of the value of education. Nevertheless, this understanding did not always filter down to the children and they sometimes decided not to continue their studies. Of course, in spite of some mothers' statements that it was their children that decided whether or not to study, it is not at all unlikely that in a filial culture like India's, the parents' desires would have an impact on the children's educational decision. Overall, it seems that it was primarily access to increased financial resources through microcredit which contributed positively to the borrowers' decision to send their children to school and college, though perhaps an appreciation of the high returns to education was a secondary reason.

\section{Conclusions}

We find that access to microfinance is not directly influential in determining parents' investment in their children's education. We do not find any substitution effect between microcredit and children's education, as Maldonado and Gonzalez-Vega (2008) and Wydick (1999) do. However, we find that microcredit access impacts the role of wealth and status on the education decision. Access to microcredit encourages parents to invest a greater amount of their wealth on children's education. Our findings seem to show that this result is primarily because microcredit directly or indirectly allows parents access to greater resources. As far as status is concerned, we find that families with a greater awareness of their social standing tend to spend more on their children's education and access to microfinance facilitates this tendency. This social status is measured by families' choice of medium of instruction and, as such, may well be a perceived status rather than an objective status. It must be cautioned, also, that our sample size is small and the results should therefore be taken to be suggestive rather than definitive.

These results are, nevertheless, gratifying in that, given research showing the value of education both to the individual and to society, provision of microcredit leads parents to invest more in education-at least under certain circumstances. The focus group results reinforce this finding since parents seem to realize the importance of education. It is also noteworthy that it is perceived status rather than objective status that leads to greater investment in children's schooling. Hence, parental education, reduced societal inequality, and growing notions of egalitarianism are likely to encourage greater investment in human capital, which is very necessary to obtain a higher rate of economic growth in developing countries. On the other hand, our results emphasize the importance of spreading awareness regarding the value of education; in the absence of such an effort accompanying microfinance activities, wealth and educational inequalities may well increase.

Acknowledgments: Expenses for survey administration were covered by the Lubin School of Business, Pace University.

Conflicts of Interest: The author declares no conflict of interest.

\section{Appendix A. Questionnaire Used for Survey}

(Note that questions in italics, though part of the original survey were not actually put to the respondents because of decisions made by the SRI interviewers in the field.)

Date and time of interview

Name of interviewer 


\section{Parents:}

Father

Name

Age

Education:

Medium of Education (Language):

Profession:

Caste:

How important is education considered in your immediate and extended family?

In your opinion, how important is education? (On a scale of 1-5)

How important did you consider education to be, five years ago?

Parent:

Mother

Name

Age

Education

Medium of Education (Language):

Profession

Caste:

How important is education considered in your immediate and extended family?

In your opinion today, how important is education? (On a scale of 1-5)

How important did you consider education to be, five years ago?

\section{Residence}

Where do you live?

How far is it from the center of Kollengode Bus Stop?

House (Own or Rent?):

How many rooms in house?

How many people live in the house?

How much land do you own?

Assets:

What are your major possessions?

Car

Other vehicle

Refrigerator

How many mobiles in the family?

Colour TV

How many Laptops/Computers:

Credit Cards:

Other:

Business (Shop, Farm, Factory etc.):

Do you have a business (If so, what?)

How many employees do you have in the business, other than your family members (full-time equivalents)?

What family members help you in the business (per week)?

How many hours do your children help out in the business (per week)?

\section{Children:}

Child 1:

Name: 
Age:

Gender:

Education:

Medium of Education (Language):

Where does s/he study?

How far is the school from his/her school?

How much do you spend on this child per month currently?

(Please explain clearly to respondent: include all expenditures that would not be necessary if the child were not being educated, such as: examination fees, cost of reading and writing materials, clothing, travelling, study tours, donation to PTA, school fees-except private tuition and coaching) Nature of expenses (note which of above list applies, as well as any others mentioned by respondent): Expenditures on child per month for private coaching:

Education plans: Will this child go on to study further, after current educational goal is achieved? Please explain, providing details of plans, if known. (For example, if this child is in primary school, will s/he go on to high school; if child is studying towards 10th standard, will s/he go on to junior college, etc.)

Expected expenses (per month) if child goes on to study further:

If child will study further, what are the reasons that you are thinking of sending this child to study further?

Do parents spend time with child on schoolwork?

How many hours per week?

Do siblings spend time with child on schoolwork?

How many hours per week?

Does anybody else spend time with child on schoolwork?

How many hours per week?

Child 2:

Name:

Age:

Gender:

Education:

Medium of Education (Language):

Where does s/he study?

How far is the school from his/her school?

How much do you spend on this child per month currently?

(Please explain clearly to respondent: include all expenditures that would not be necessary if the child were not being educated, such as: examination fees, cost of reading and writing materials, clothing, travelling, study tours, donation to PTA, school fees-except private tuition and coaching) Nature of expenses (note which of above list applies, as well as any others mentioned by respondent): Expenditures on child per month for private coaching:

Education plans: Will this child go on to study further, after current educational goal is achieved? Please explain, providing details of plans, if known. (For example, if this child is in primary school, will s/he go on to high school; if child is studying towards 10th standard, will s/he go on to junior college, etc.)

Expected expenses (per month) if child goes on to study further:

If child will study further, what are the reasons that you are thinking of sending this child to study further? 
Do parents spend time with child on schoolwork?

How many hours per week?

Do siblings spend time with child on schoolwork?

How many hours per week?

Does anybody else spend time with child on schoolwork?

How many hours per week?

Child 3:

Name:

Age:

Gender:

Education:

Medium of Education (Language):

Where does s/he study?

How far is the school from his/her school?

How much do you spend on this child per month currently?

(Please explain clearly to respondent: include all expenditures that would not be necessary if the child were not being educated, such as: examination fees, cost of reading and writing materials, clothing, travelling, study tours, donation to PTA, school fees-except private tuition and coaching) Nature of expenses (note which of above list applies, as well as any others mentioned by respondent): Expenditures on child per month for private coaching:

Education plans: Will this child go on to study further, after current educational goal is achieved? Please explain, providing details of plans, if known. (For example, if this child is in primary school, will s/he go on to high school; if child is studying towards 10th standard, will s/he go on to junior college, etc.)

Expected expenses (per month) if child goes on to study further:

If child will study further, what are the reasons that you are thinking of sending this child to study further?

Do parents spend time with child on schoolwork?

How many hours per week?

Do siblings spend time with child on schoolwork?

How many hours per week?

Does anybody else spend time with child on schoolwork?

How many hours per week?

SRI:

Did you get any information on education from SRI? If so, what?

If so, how important was it in your decision to spend money on your children's education?

What kind of job would you like your children to get, once they finish their studies?

When did you become a member of SRI?

How many loans have you taken from SRI?

For what purpose have you taken loans from SRI?

What is the amount of your current indebtedness to SRI (total amount of your loans)?

Other banks or microfinance institutions:

Do you have loans from other institutions?

How long have you had an association with other institutions? 
For what purpose have you taken loans from other institutions?

What is the amount of your current indebtedness to SRI (total amount of your loans)?

What is the amount of your current indebtedness to other institutions (total amount of your loans)?

\section{Appendix B. Grandparents' Occupation Grouping}

\begin{tabular}{|c|c|c|}
\hline Response & Assumed Sector & Job Class \\
\hline No & Does Not Work & 0 \\
\hline- & Does Not Work & 0 \\
\hline Beediwork & Labor & 1 \\
\hline Coolie & Labor & 1 \\
\hline Daily Wages & Labor & 1 \\
\hline Labour & Labor & 1 \\
\hline Labour in Soda company & Labor & 1 \\
\hline Bricks Work & Construction & 1 \\
\hline Laundry & Services/Labor & 1 \\
\hline Quarry Work & Services/labor & 1 \\
\hline Quarry & Services/Labor & 1 \\
\hline Tailor & Services & 2 \\
\hline Tea Shop & Retail & 2 \\
\hline Toddy Shop & Food \& Beverage & 2 \\
\hline Vegetable Business & Agriculture & 2 \\
\hline Wood Work & Construction & 2 \\
\hline Agriculture & Agriculture & 3 \\
\hline Farmer & Agriculture & 3 \\
\hline Farming & Agriculture & 3 \\
\hline Fish Business & Agriculture & 3 \\
\hline Goat Rearing & Agriculture & 3 \\
\hline Astrologer & Services & 4 \\
\hline Kerala State Electricity Board & Employment & 5 \\
\hline Building Contractor & Construction & 6 \\
\hline
\end{tabular}

Note: This table shows the actual responses that were obtained to the question of grandparents' occupation and how they were classified and ranked. As mentioned in the text of the paper, the job class variable, though clearly categorical, was treated as an interval variable for convenience in using it in the regression.

\section{Appendix C. Focus Groups}

As mentioned earlier, the second half of the study consisted of focus group interviews. These interviews were undertaken when the students actually visited SRI in Kollengode, Palghat in January 2016. About half of the 38 survey respondents were chosen randomly to participate in this second component. The 17 students participating in the survey formed five different groups (A-E). Each group was provided with an interpreter. The purpose of this second phase was to allow us to flesh out the human background to the data collected Phase One by the SRI interviewers administering the survey described in Appendix A.

During these focus group interviews, students asked questions to try and obtain qualitative answers to questions such as:

1. How important is education to the respondent (usually the mother)? Maybe ask her to compare it with other things...

2. Why is education important?

3. Have her ideas of the importance of education changed over time?

4. Where do you get the financing for funding your children's education?

5. How far do you want to educate your child? Will this child go on to study further, after current educational goal is achieved? Please explain, providing details of plans, if known. (For example, if this child is in primary school, will s/he go on to high school; if child is studying towards $10^{\text {th }}$ standard, will s/he go on to junior college, etc.) 
6. Is education important to get a government job? Or is it only important to get a private sector job?

7. What are your aspirations regarding the kind of job that you want your child to have?

8. Do you think it's more important for boys to study than girls? Why or why not?

9. Does everybody in your family share your views regarding education?

10. Do your friends share your views regarding education?

11. Have your views of education changed after becoming clients of SRI?

12. What sorts of education-related expenses do you have?
a. examination fees,
b. cost of reading and writing materials,
c. clothing,
d. travelling,
e. study tours,
f. donation to PTA,
g. school fees,
h. private tuition and coaching,
i. other

13. Would you take loans to send your children to college or to pay for coaching or special tuition?

14. Do you think that caste status or other social status can be transcended by education?

15. Do you think that education is more important for people of higher caste or social status?

16. Would the need for your children to help you with your business or farm be a factor in your decision to send him/her to school?

\section{References}

Adjei, Joseph Kimos, Thankom Arun, and Farhad Hossain. 2009. The Role of Microfinance in Asset-Building and Poverty Reduction: The Case of Sinapi Aba Trust of Ghana. BWPI Working Paper 87; Manchester: Brooks World Poverty Institute.

Alkire, Sabina, and Andy Sumner. 2013. Multidimensional Poverty and the Post-2015 MDGs. Development 56: 46-51. [CrossRef]

Augsburg, Britta, Ralph De Haas, Heike Harmgart, and Costas Meghir. 2015. The Impacts of Micro-credit: Evidence from Bosnia and Herzegovina. American Economic Journal: Applied Economics 7: 183-203.

Barrientos, Armando, and David Hulme. 2008. Social Protection for the Poor and Poorest in Developing Countries: Reflections on a Quiet Revolution. BWPI Working Paper 30; Manchester: Brooks World Poverty Institute.

Behrman, Jere, and James Knowles. 1999. Household income and child schooling in Vietnam. The World Bank Economic Review 13: 211-56. [CrossRef]

Behrman, Jere, and Mark Rosenzweig. 2002. Does increasing women's schooling raise the schooling of the next generation? American Economic Review 92: 323-34. [CrossRef]

Behrman, Jere, and Emmanuel Skoufias. 2010. The Economics of Conditional Cash Transfers. In Conditional Cash Transfers Programs in Latin America: A Synthesis of Their Impacts on Education, Health and Nutrition. Edited by Michelle Adato and John Hoddinott. Baltimore: Johns Hopkins Press for the International Food Policy Research Institute, pp. 127-58.

Breen, Richard, and John Goldthorpe. 1997. Explaining Educational Differentials. Towards a Formal Rational Action Theory. Rationality and Society 9: 275-305. [CrossRef]

Cull, Robert, Asli Demirgüç-Kunt, and Jonathan Morduch. 2009. Microfinance Meets the Market. The Journal of Economic Perspectives 23: 167-92. [CrossRef]

Dreze, Jean, and Amartya Sen. 1995. India: Economic Development and Social Opportunity. Chennai: Oxford University Press.

Duflo, Esther. 2012. Women Empowerment and Economic Development. Journal of Economic Literature 50: 1051-79. [CrossRef] 
Edmonds, Eric V. 2006. Child Labor and Schooling Responses to Anticipated Income in South Africa. Journal of Development Economics 81: 386-414. [CrossRef]

George, Ann. 2001. Multiple Dimensions of Well Being: A Micro Level Study of the Poor. MPhil dissertation, Centre for Development Studies (CDS), Thiruvananthapuram, India.

Grosse, Melanie, Kenneth Harttgen, and Stephan Klasen. 2008. Measuring Pro-Poor Growth in Non-Income Dimensions. World Development 36: 1021-47. [CrossRef]

Hulme, David. 2007. Imagining Inclusive Globalisation: India's Role in Tackling Global Poverty. Exim Bank of India Annual Commencement Day Lecture 2007; Mumbai: Exim Bank.

Hulme, David, and Andrew Shepherd. 2003. Conceptualizing Chronic Poverty. World Development 31: 403-23. [CrossRef]

Jacoby, Hanan, and Emmanuel Skoufias. 1997. Risk, Financial Markets, and Human Capital in a Developing Country. The Review of Economic Studies 64: 311-35. [CrossRef]

Khandker, Shahidur. 1998. Fighting Poverty with Microcredit: Experience in Bangladesh. Washington: The World Bank.

Kumar, Ajith N., and K. K. George. 2009. Kerala's Education System: From Inclusion to Exclusion? Economic and Political Weekly 44: 55-61.

Lee, Keun, and Byung-Yeon Kim. 2009. Both Institutions and Policies Matter but Differently for Different Income Groups of Countries: Determinants of Long-Run Economic Growth Revisited. World Development 37: 533-49.

Maldonado, Jorge, and Claudio Gonzalez-Vega. 2008. Impact of Microfinance on Schooling: Evidence from Poor Rural Households in Bolivia. World Development 36: 2440-55. [CrossRef]

Mathew, Shalini. 2015. Falling Female Labour Force Participation in Kerala: Empirical Evidence of Discouragement. International Labor Review 154: 497-518. [CrossRef]

Mobolaji, Hakeem. 2010. Banking development, human capital and economic growth in Sub-Saharan Africa (SSA). Journal of Economic Studies 37: 557-77.

Schneider, Brit S., Udo Schneider, and Volker Ulrich. 2007. Health and the Decision to Invest in Education. Jahrbücher für Nationalökonomie und Statistik/Journal of Economics and Statistics 227: 725-45. [CrossRef]

Stocké, Volker. 2007. Explaining Educational Decision and Effects of Families' Social Class Position: An Empirical Test of the Breen-Goldthorpe Model of Educational Attainment. European Sociological Review 23: 505-19. [CrossRef]

Tarozzi, Alessandro, Jaikishan Desai, and Kristin Johnson. 2015. The Impacts of Microcredit: Evidence from Ethiopia. American Economic Journal: Applied Economics 7: 54-89.

United Nations Development Programme (UNDP). 2006. Kerala Human Development Report, 2005. Available online: http:/ / hdr.undp.org/en/content/kerala-hdr-2005 (accessed on 4 January 2018).

Viswanath, Plachikkat. 2015. Microfinance and Investment in Human and Social Capital. ACRN Journal of Finance and Risk Perspectives 4: 81-101.

Viswanath, Plachikkat. 2018. Microcredit and Survival Microenterprises: The Role of Market Structure. International Journal of Financial Studies 6: 1. [CrossRef]

Wydick, Bruce. 1999. The Effect of Microenterprise Lending on Child Schooling in Guatemala. Economic Development and Cultural Change 47: 853-69. [CrossRef]

Yang, Dennis. 2004. Education and allocative efficiency: household income growth during rural reforms in China. Journal of Development Economics 74: 137-62. [CrossRef]

(c) 2018 by the author. Licensee MDPI, Basel, Switzerland. This article is an open access article distributed under the terms and conditions of the Creative Commons Attribution (CC BY) license (http://creativecommons.org/licenses/by/4.0/). 